\title{
COMMUNICATION
}

\section{ON CAPITAL PUNISHMENT - A COMMENT}

It is rare to read an article on such an emotionally charged topic as capital punishment without gaining the impression that the author's arguments merely reflect his "gut" feeling as to whether the retention of this institution in contemporary society is right or wrong. Professor Igor Primorac ("On Capital Punishment" (1982) 17 Is.L.R. 133-150), on the other hand, although defending society's right to employ this penalty, refrains from taking a one-sided position: he is willing to admit that the utilitarian arguments favouring the death penalty are not persuasive, and to rest his case on retributive grounds alone. In so doing, he exposes a number of fallacies inherent in the arguments of many of the critics of the retributive approach, who one suspects have not always been free of the type of gut feeling referred to. However, to the present writer (who also makes no claim to freedom from such prejudices) there appear to be four issues raised by Professor Primorac, whether explicitly or implicitly, which are deserving of comment.

\section{Utilitarianism and Retributivism}

The first point concerns the relationship between the utilitarian and the retributive approaches to punishment. Prof. Primorac presents these as discrete alternatives: "The nature of the arguments will depend on whether we subscribe to the first or the second of these two rationales of punishment in general" (p. 134). He then goes on to argue that while utilitarians may have no adequate basis for advocating the death penalty, a retributivist approach serves as a justification for this penalty.

However, the utilitarian and retributive approaches are not necessarily mutually exclusive. Indeed, probably a majority of the population would instinctively expect punishments to satisfy certain criteria pertaining to both the retributivist and the utilitarian philosophies. (This approach has been articulately presented in Honderich's Punishment - The Supposed Justifications). ${ }^{1}$

1 Harmondsworth, Penguin Books, 1971. For other examples of a "mixed philosophy" - including Professor Hart's well-known distinction between the General Justifying Aim and the Principle of Distribution - see R. Singer, Just Deserts, 
The adoption of such a "mixed" philosophy might lead to one of the following positions: (a) that punishment should be accorded in general upon utilitarian grounds, but subject to the reservation of a modicum of proportionality as dictated by retributivist concepts; or (b) that punishments should generally be based upon retributivist principles, but only in so far as there are no strong utilitarian grounds for departing from these principles. ${ }^{2}$ Persons holding position (a) may be labelled "qualified utilitarians" and would presumably reject the death penalty on the grounds enumerated by Prof. Primorac. We are concerned here rather with the "qualified retributivists" of category (b). Retributivists of this ilk might accept all Prof. Primorac's arguments favouring the death penalty on retributivist grounds, but might nevertheless be persuaded that there were overriding utilitarian grounds for its rejection. One such ground might be the view that adoption of the death penalty leads to the devaluation of human life thereby giving rise to an increase in the rates of murder and violence in the community; ${ }^{3}$ another, that invoking the death penalty for terrorists creates martyrs and thereby results in increased acts of terrorism. Adopting such arguments, a "qualified" retributivist might agree to abandon his advocacy of a penalty otherwise seen to be acceptable on retributivist grounds.

The other three points to be commented upon derive from Prof. Primorac's arguments in defence of the retributivist position, or in refutation of its critics.

\section{Error}

A well-known criticism of the retributivist justification of the death penalty is based upon the possibility of a miscarriage of justice. This argument was summarized by Prof. Primorac in his article as follows: "In all other cases of mistaken sentencing we can revoke the punishment, either completely or in part, or at least extend compensation. In addition to that, by exonerating the accused, we give him moral satisfaction. None of this is possible after an innocent man has been executed; capital punishment is essentially different from all other penalties by being completely irrevocable and irreparable. Therefore, it ought to be abolished." (p. 144).

(Cambridge, Mass., Ballinger, 1979); see also, in the context of capital punishment, Margaret Jane Radin, "The Jurisprudence of Death: Evolving Standards for the Cruel and Unusual Punishments Clause", (1978) 126 U. Pa. L. R. 989, 1049-1056.

2 Naturally this could not apply to an absolute retributivist of the Kantian school.

3 This explanation is sometimes offered for the high murder rates obtaining in the Southern states of the U.S., where capital punishment has been widely used. 
Professor Primorac implicitly admits the possibility of such. errors but he argues that "...this is not something that stems from the intrinsic nature of the institution of capital punishment; it results from deficiencies, limitations, imperfections of the criminal law procedures in which this punishment is meted out. So these errors of justice do not demonstrate the need to do. away with capital punishment; they simply make it encumbent upon us to do everything possible to improve even further the procedures of meting it out." (p. 145). It is true, of course, that the possibility of a miscarriage of justice does not impinge on the concept of capital punishment as a just penalty for murder. However, a penalty cannot be just in practice unless there is a just procedure for its application. Now, while the frequency of error may derive from "deficiencies, limitations, imperfections of the criminal law procedures", the possibility of error is rather something inherent in any legal system. It is not a coincidence that both the critics and Prof. Primorac alert to the danger of miscarriages of justice in general, and not to the deficiencies of any particular legal system; for the phenomenon is universal. "To do everything possible" to improve the procedures will never eradicate the risk entirely; this was essentially the path trodden by Jewish law, under which the precautions developed to prevent such occurrences resulted in the effective abolition of the death penalty. ${ }^{4}$ For judicial findings are essentially probabilistic - statements, ${ }^{5}$ which inevitably leave room for a degree of residual doubt. Indeed, this characteristic of criminal justice has been recognized and institutionalized in many legal systems (including our own) by the establishment of the "retrial", a proceeding designed expressly to evaluate the likelihood that an earlier judicial decision was based upon error. ${ }^{6}$ Thus while there may indeed be no special risk of error deriving from "the intrinsic nature of the institution of capital punishment", such a risk does, however, stem from the intrinsic nature of the criminal process - and, one might add, from human fallibility. ${ }^{7}$

4 Hyman E. Goldin, Hebrew Criminal Law and Procedure (New York, Twayne Publishers, 1952) 26.

5 Cf. Richard Eggleston, Evidence, Proof and Probability (London, Weidenfeld \& Nicolson, 1978) 102.

6 The controversial Baranes case comes to mind here. Irrespective of the final outcome of the pending investigation into the possibility of a miscarriage of justice in this case, can one imagine the moral horror which would accompany these deliberations were the defendant to have been executed?

7 Cf. Radin (op. cit., supra n. 1 at 1064): "If infallibility is to be required for any case, it should be required where the deprivation is irrevocable; and if infallibility is to be required in any case in which the deprivation is irrevocable, it should be required where the irrevocable deprivation is of life itself". 
At this point, Prof. Primorac has a "fall-back position". It is surely implausible, he argues, "to claim that there have never been cases of murder which left no room whatever for reasonable doubt as to the guilt and full responsibility of the accused.$^{8}$ So why not retain the death penalty at least for them?" (pp. 144-145).

In view of the common occurrence of distortions in perception and errors of recall, ${ }^{9}$ and the additional (although thankfully rarer) possibilities of prevarication and frame-up by witnesses and occasionally even by law enforcement authorities, such "watertight" cases may occur more rarely than the writer suggests and their identification may be impossible." However, even if there were such cases, Prof. Primorac's proposal would seem to be both impracticable and unjustifiable for the following reasons:

(a) The imposition of the death penalty would have to be a discretionary measure, since it would be applied only to the "certain" cases. This would result in inevitable tensions and pressures, and the exercise of (costly) forensic skills both at the sentencing stage of the trial and on appeal, as well as in the context of a possible retrial and a clemency decision.

(b) Persons not receiving the death penalty would have been effectively labelled by the system "probably guilty", and would have an apparently legitimate basis for declarations of innocence and - again - for petitions for retrials and clemency.

(c) The decision whether or not to impose the death penalty would depend not upon the heinousness of the crime but rather on the strength of the evidence of its commission. This result is totally inconsistent with Prof. Primorac's overriding concern with proportionality. One of his main arguments in defence of the death penalty is that he cannot tolerate the injustice he perceives in the non-imposition of the death sentence on murderers, the only punishment which in his view corresponds with the seriousness of the offence, while other offenders, guilty of lesser crimes, are receiving their due measure of punishment. How then could he advocate a

8 The unequivocability of the tone ("no room whatever") is somewhat modified by the qualification of the nature of the doubt ("reasonable"). Perhaps in capital cases, bearing in mind the irrevocability of the outcome, even unreasonable doubts may be entertained?

9 See e.g., James Marshall, Law and Psychology in Conflict, (Indianapolis, BobbsMerrill, 2nd ed., 1980) Chap. 1.

10 Prof. Primorac's approach recognizes the occurrence of human error in the decision-making process. There thus seems to be a logical difficulty here: If we recognize the possibility of human error, how can we be sure that the assessment of a particular case as being free from error, will not itself be made in error? 
policy which would involve the selective imposition of the death penalty based upon grounds unrelated to the seriousness of the offence committed?

\section{Proportionality I: Differentials}

As noted, in arguing against the need to take into account the possibility of a miscarriage of justice, Prof. Primorac is concerned at the possibility of an infringement of the principle of proportionality: "Murderers would not be receiving the only punishment truly proportionate to their crime, the punishment of.death, but some other, lighter and thus disproportionate penalty. All other offenders would be punished according to their deserts; only murderers would be receiving less than they deserve" (p. 145). This possibility is subsequently described as "a grave injustice" (p. 146) presumably to the "other offenders", but perhaps to society as a whole.

The emphasis on proportionality here in fact masks a fusion of two distinct principles which must be differentiated in order to assess the validity of Prof. Primorac's approach. To argue that the death penalty is the "only punishment truly proportionate" to the crime of murder is an argument for the appropriateness of this particular punishment for this particular crime, and may for convenience (in order to differentiate it for proportionality in a second sense) be referred to as the principle of equivalence. This indeed is the term used by Prof. Primorac in the earlier section of the article in which he presents his fundamental position on the retributivist justification for the death penalty.

The principle of equivalence (which will be discussed below) must be distinguished from another principle which states as follows: The more serious the offence, the more severe the penalty. This principle is inherent in (although not exclusive to ${ }^{11}$ ) all retributivist schemes of punishment, ${ }^{12}$ but its advocacy has no direct bearing on the issue of capital punishment. For it says nothing about either the range or the type of penalties to be imposed, but addresses the issue of the measure of differentiation between them. Thus, in Anglo-Saxon times, the penalty usually took the form of pecuniary compensation (the bot), while in the case of homicide a special payment had to be made (the wer)..$^{13}$ Although under this system

11 Beccaria advocated the same principle but based it upon a deterrence philosophy: See Cesare Beccaria, On Crimes and Punishments (Indianapolis, Bobbs-Merrill, 1963) Chap. XXIII.

12 Cf. H.L.A. Hart, Punishment and Responsibility (Oxford, Clarendon Press, 1968) 233-234.

13 See, e.g., Richard Korn \& Lloyd McCorkle, Criminology and Penology (New York, Holt, Rinehart and Winston, 1960) 387. 
murderers were not normally executed, there was surely no "injustice" here to the non-murderer, whose burden of compensation was less than that of the murderer. Similarly, there has recently been a strong movement towards proportional sentencing (rejecting the rehabilitationist approach of an individualized sentence); but its supporters do not necessarily advocate the death penalty. Indeed, the Committee for the Study of Incarceration whose report contributed so significantly to the revival of this philosophy - generally recognized as being retributivist ${ }^{14}$ - advocated the use of rather low penalties; most serious offences would be punishable by terms of imprisonment between eighteen months and two years. ${ }^{15}$ It is true that some advocates of this approach favour heavier penalties, and that the era of neo-retributivism has seen the reinstitution in the United States of the death penalty; but there is no necessary connection between these two developments. Some social scientists have attempted a pseudo-scientific solution to the question of what is the proper differential between the punishment for any two offences. ${ }^{16}$ This involves the development of seriousness scales for offences and severity scales for penalties, ${ }^{17}$ and the assumption of unidimensionality as between the two scales. Let us suppose it were to emerge from such studies that the differential between the score for murder and the score for, say, manslaughter or rape, were equal to the differential between the scores for the death penalty and life imprisonment respectively. (Such a finding seems on present evidence to be unlikely, ${ }^{18}$ but this type of research is still in its infancy - at least in respect

14 M. Gardner, "The Renaissance of Retribution - An Analysis of 'Doing Justice", (1976) Wis. L. R. 781-815.

15 See the publication of the Committee's Report: Andrew von Hirsch, Doing Justice (New York, Hill and Wang, 1976) 138-139.

16 See, e.g., Marvin E. Wolfgang, "Current Trends in Penal Philosophy" (1979) 14 Is.L.R. 43-59.

17 These scales are produced by eliciting from respondents the attribution of scores for various offences or penalties, which will reflect their seriousness or severity. This type of technique is known as "psychophysical scaling", and was developed in a famous study by T. Sellin and M.E. Wolfgang, The Measurement of Delinquency (New York, Wiley, 1964). The application of the technique to the scaling of sanctions rather than offences, and the attempts to link the respective scales, are somewhat recent.

18 Present research seems to indicate enormous differences in the perceived severity of the death penalty and life imprisonment - at least where life imprisonment envisages an ultimate release. See: L. Sebba, Further Explorations in the Scaling of Penalties, Paper presented at the Annual Meeting of the American Society of Crimonology, November 1981; cf. V.L. Hamilton \& L. Rotkin, "Interpreting the Eighth Amendment: Perceived Seriousness of Crime and Severity of Punishment", in H.A. Bedau \& C.M. Pierce (eds.), Capital Punishment in the United States (New York, AMS Press, 1976). 
of the penalty aspect.) Even such a finding would not necessarily be an argument for capital punishment, for the same differential could probably be found lower down in the penalty scale, say between life imprisonment and ten years imprisonment, which could be respectively adopted for murder and rape.

Finally, it may be argued that this principle of proportionality would in itself preclude the use of the death penalty for all except the most brutal murders, in order to maintain a differential sanctioning level for murders of varying degrees of seriousness. ${ }^{19}$

\section{Proportionality II: Equivalence}

Professor Primorac's initial defence of the death penalty was based on proportionality in the sense of equivalence between the crime and the punishment. Moreover he adopts a very fundamentalist interpretation of this principle. ${ }^{20} \mathrm{He}$ invokes the Biblical principle of talio, ("an eye for an eye", etc.), which although not applicable for other offences (p. 137), he believes to be uniquely applicable in cases of murder: "There is nothing equivalent to the murderous destruction of a human life except the destruction of the life of the murderer" (p. 138).

While in principle the Bible clearly lends support to the idea of capital punishment for murder, two comments may be made here. First, this penalty cannot be considered to have been uniquely appropriate for murder, since it was available - at least in Biblical times - for other offences too. Secondly, the talionic principle took two forms, "identical" talios and "equivalent" talios. ${ }^{21}$ In the latter case the connection between the punishment and the offence are merely symbolic (e.g., cutting off the hand of a thief); and it was in this sense that the talio was applied in Talmudic

19 See Von Hirsch, op. cit., supra n. 15, note on p. 139.

${ }^{20} \mathrm{Cf}$. the Committee for the Study of Incarceration (above, n. 15), whose principle of "commensurate deserts" seems to incorporate the principle of Proportionality II: Equivalence as well as Proportionality I: Differentials. (See the opening statement of Chapter 8: "If one asks how severely a wrongdoer deserves to be punished, a familiar principle comes to mind: Severity of punishment should be commensurate with the seriousness of the wrong" (Italics in original)): Yet for murder the Committee suggested terms of imprisonment from five years and upward; there is thus no attempt to achieve equivalence in a literal sense. Other standards for determining proportionality in this sense are discussed in Radin (n. 1 above at 1057-1062).

21 See H.H. Cohn, "Talion" in M. Elon (ed.), Jewish Law (Jerusalem, Keter Publishing House, 1975) col. 525. 
times. ${ }^{22}$ It could perhaps be argued that talio in this sense could be achieved by imposing on murderers a life sentence-a form of "civil death", with its accompanying loss of liberty and amenities.

However, the main argument against the application of the talionic principle to murder alone is that it directly conflicts with the preceding principle so enthusiastically (and apparently unequivocally) approved by Prof. Primorac, namely, the need for proportionality in sanctioning as among various types of offence. If one must take care not to cause injustice by giving murderers less than their due, why does not the same apply to non-murderers? For if the principle of Proportionality II: Equivalence applies to one type of offence and not to another, the principle of Proportionality I: Differentials is necessarily infringed.

On the other hand Prof. Primorac refrains from advocacy of equivalent sanctions for non-murderers. Indeed, it seems doubtful whether anyone would propose the application of an identical talio for such offenders (i.e., by having them assaulted, raped, etc.) - while few would advocate an equivalent talio ${ }^{23}$ (amputation of limb, castration etc.). Prof. Primorac effectively rejects this type of penalty in the course of his reservations regarding the possibility of administering torture to a torturer, by postulating that a punishment should not be "cruel in an absolute sense", or "something indecent and inhuman" (p. 150). ${ }^{34}$ But he has in any case already rejected the need for talionic punishments for any offence other than murder because of "the uniqueness of this crime" (p. 137). However to apply an equivalent or talionic punishment for murder alone would amount to discrimination between murderers and non-murderers, and would result in the very type of injustice which Professor Primorac seeks to avoid.

Leslie Sebba*

22 lbid.

23 The search for non-talionic equivalents is even more problematic: see H.A. Bedau, "Retribution and the Theory of Punishment", (1978) 75 J. of Philosophy, 601, 611-615. See also above n. 16. However, non-talionic equivalence provides no obvious justification for the application of capital punishment to murderers, and was thus not invoked by Prof. Primorac.

24 Cf. the "dignity" standard invoked by the U.S. Supreme Court: see Radin, op. cit., supra n. 1 at 1044-1045, 1053-1054.

* Dr. Jur. (Jerusalem); Senior Lecturer, Institute of Criminology, Faculty of Law, The Hebrew University of Jerusalem. 